DISMISSED OR WITHDRAWN.

2344. "The Warren Rotary Engine."

2346. "Morris's Portable Roof."

\title{
REPORT OF THE COMMITTEE ON MEETINGS FOR THE YEAR 1905.
}

To the President and Members of the Franklin Institute:

The Committee on Meetings has arranged the programs of the usual number of meetings, with the assistance of the Secretary of the Institute. The Committee has nothing of special interest to report, and can only reiterate the statement contained in its report for the previous year, namely, that the growing activities of the Sections render it increasingly more difficult to retain for the monthly meetings the conspicuous place they occupied for many years.

The policy of preserving for presentation and discussion at the monthly meetings, subjects of general popular interest will be continued.

Respectfully submitted,

Washington Jones,

Chairman Committee on Meetings.

Philadelphia, PA., January 3, 1906.

\section{REPORT OF THE COMMITTEE ON PUBLICATIONS FOR THE YEAR 1905.}

To the Board of Managers:

Gentremen:-The Committee on Publications respectfully reports that the quantity of material offered for publication has been ample for its requirements. The Committee feels that the managers and members have cause for congratulation in the fact that the contributions to its pages through the Sections, meetings of the Institute and the several committees have made the Journal in recent years, what its name implies, the Journal of the Franklin Institute, indicating as it does, the continued scientific activity of the Institute. By reason of its contract entered into early in the year, the Committee is pleased to be able to say that the cost of publication has been greatly reduced and that it hopes to continue this economy for the future.

H. W. JAYNE, Chairman Committee on Publication.

Philadelphia, PA., January 4, 1906.

REPORT OF THE COMMITTEE ON INSTRUCTION FOR THE YEAR I905.

To the Board of Managers:

The Committee on Instruction has been much gratified by the interest shown by members in the annual courses of popular scientific lectures, 